\title{
Trichoderma in Agriculture: An Overview of Global Scenario on Research and its Application
}

\author{
K.K. Sharma* \\ Regional Research Station (PAU), Ballowal Saunkhri, Teh. - Balachaur, District - SBS \\ Nagar, PIN - 144521, Punjab (India) \\ *Corresponding author
}

A B S T R A C T

\begin{tabular}{|l|}
\hline K e y w o r d s \\
Antibiosis, \\
Antagonist, Bio- \\
control, ISR, \\
Trichoderma
\end{tabular}

Introduction

The organism that suppresses the pathogen or its activity is referred as biological control agent (BCA) and phenomenon known as biocontrol or biological control. The species of Trichoderma are universally known for their bio-control potential in addition to plant growth and development (Vinale et al., 2014). An effective and potential BCA (microbial pesticide) must have some unique characteristics for successful bio-control of plant diseases i.e. i) good shelf life and survival in the soil in its inactive or active form, ii) host specificity, iii) easy to multiply in laboratory and iv) ecofriendly and cost effective. The phenomenon of bio-control employed by Trichoderma is governed by a variety of mechanism either its direct presence at the infection site or passively due to its activities which triggers and activates the various biochemical pathways in plant system. Hence, lot of research has been focused on characterizing the unique mechanism(s) used by a particular BCA operating in different experimental situations. The variety of registered microbial agents viz. bacteria (Pseudomonas aureofaciens, 
Pseudomonas fluorescens, Bacillus subtilis, Agrobacterium radiobacter, Streptomyces griseoviridis), nematodes, protozoa viruses and fungi (Ectomycorrhizae sp., Cladosporium sp. Ampelomyces quisquallis, Coniothyrium minitans, Aspergillus niger IARI isolate) including Trichoderma species (T. harzianum, $T$. viridiae, $T$. virens) are being utilized in plant disease control as the bio-pesticide (Gardener and Fravel, 2002; Koul, 2011). In this review, various mechanisms employed by Trichoderma, present scenario of research and its application are being discussed.

\section{Direct mechanism}

\section{Mycoparasitism/Hyperparasitism}

More than seventy reports on mycoparasitic ability of Hypocrea/Trichoderma species are documented against phytopathogenic fungi such as Alternaria alternata, Botrytis cinerea, Rhizoctonia solani, Sclerotinia sclerotiorum, Pythium spp., Phytophthora sp. and Fusarium spp. (Harman 2006; Druzhinina et al., 2011; Atanasova et al., 2013; Bae et al., 2016) and it is one of the chief mechanisms involved in the antagonism and bio-control efficacy of Trichoderma spp. (Sharon et al., 2001). This process involves tropic growth of the biocontrol agent towards the target organism, coiling and finally enzymatic dissolution of cell wall / cell membrane of the target organism where not only an antagonist, but also target pathogen responsible to govern the nature of antagonism. In a study, it was reported that some strains of $T$. harzianum have ability to parasitize on nematodes and their egg masses also where it coiled around the second stage juveniles of Meloidogyne javanica and penetrated them by forming haustoria like structures (Sahebani and Hadavi, 2008). Trichoderma longibrachiatum was also reported to manage Heterodera avenae (Zhang et. al., 2014a) and
Meloidogyne incognita (Zhang et. al., 2015) where it showed its bio-control potential.

\section{Antibiosis}

It is an antagonistic association between two microorganisms, in which one is adversely affected due to metabolites or antibiotics released by another. The chemical and analytical reports portray that 373 different secondary metabolites such as peptaibols, NRPs, volatile and non-volatile terpenes, pyrones and nitrogen containing compounds obtained from species of Trichoderma revealed their great potential to produce antibiotics and secondary metabolites (Mukherjee et al., 2012a; Mukherjee et al., 2012b; Crutcher et al., 2013; Bae et al., 2016; Contreras-Cornejo et. al., 2016). Gliotoxin and glyoviridin from $T$. virens (Wilhite et al., 2001), viridin, alkylpyrones, isonitriles, polyketides, peptaibols, diketopiperazines and sesquiterpenes isolated from Trichoderma spp. (Singh et al., 2001b; Reino et al., 2008), trichodermin (Tijerino et al., 2011; Shentu, et al., 2013) and 6-Pentyl-2H-pyran-2-one (Garnica-Vergara et al., 2015) are some of the examples which are found effective against target pathogen in-vitro and/or in-situ.

\section{Competition and rhizosphere competence}

The most abundant non-pathogenic plantassociated microbes are generally thought to protect the plant by rapid colonization and thereby exhausting the limited available substrates so that none are available for pathogens to grow. Being a living organism, competition is considered as a 'classical' mechanism of Trichoderma in biological control. The omnipresence of Trichoderma in agricultural and natural soils throughout the world proves that it must be an excellent competitor for space and nutritional resources. Tsahouridou and Thanassoulopoulos (2002) found the $T$. 
koningii as rhizosphere competent when treated tomato seeds with conidial suspension of $T$. koningii were sown which resulted in reduced damping-off pathogen.

\section{Sclerotia colonization and parasitization}

The phytopathogens like Rhizoctonia solani, Sclerotium rolfsii and Sclerotinia spp. have tremendous ability to survive in soil for decades through hardy structures 'sclerotia' which are highly resistant to fungicides and microbial degradation and hence, play important role in disease cycle of the pathogen (Metcalf et al., 2004, Abdulla et al., 2008). The idea of sclerotia parasitization or killing them using microbial antagonist may be a key point for successful biological control. However, species of Trichoderma are also known for their ability to degrade cellulose and chitin (Balakrishnan et al., 2012, Barakat et al., 2013). In previous studies it was reported that the sclerotia of Rhizoctonia solani and S. rolfsii are colonized by Trichoderma, completely rotted and do not germinate if parasitized by Trichoderma (Rawat and Tewari, 2010; Sharma, 2017).

\section{Indirect mechanism}

\section{Induction of host resistance}

Besides the ability to attack directly or inhibit the growth of plant pathogens, some of the bio-control strains of Trichoderma sp. are known to strongly induce systemic resistance (ISR) and host plant defense against a variety of plant pathogens which is mediated by jasmonic acid (JA)/ethylene (Harman 2004; Pal and Gardener, 2006). In a study, the isolates of endophytic Trichoderma from tropical environments reported to induce resistance against Phytophthora capsici in hot pepper and delayed the disease onset (Bae et al., 2011). Yedidia et al., (2003) gave evidence of induction of a systemic response by root application of $T$. asperellum which protect the cucumber plant against angular leaf spot. Induced resistance in tomato plant (cv. Sida cultivar) against bacterial leaf spot (Xanthomonas campestris pv. vesicatoria) with $69.32 \%$ reduction in disease was reported by Saksirirat et al., (2009) after 14 days post inoculation of T. harzianum (T9). A protective effect of Trichoderma on plants was strongly inhibited when treated with an inhibitor of ethylene which confirmed the essential role of ethylene signal in ISR (Shoresh et al., 2005). Moreover, there are some other reports which evidenced that species of Trichoderma are abile to induce plant defense mechanisms (Shoresh, et. al, 2010; Contreras-Cornejo et al.2011; Sharma, 2017). Research is initiated from last decade to characterize the determinants and biochemical pathways of induced resistance correlated with bio-control agents including Trichoderma and other non-pathogenic microbes.

\section{Plant growth promotion}

Bio-control agents, both fungal and bacterial, are reported to induce the growth of various crops. These responses may be due to the individual and /or cumulative effect of (i) suppression of deleterious root micro-flora, (ii) production of growth hormones or growth factors (Contreras-Cornejo et al.2011, 2014a; Martínez-Medina et al., 2014) and/or (iii) increased nutrient uptake through solubilization and sequestration of nutrients and/or enhanced root growth (Viterbo et al., 2002). Species of Trichoderma are unique groups of rhizospheric microorganisms associated with certain beneficial effects to enhance plant growth and development. The research by several independent research groups have observed the increased growth of various crops with the use of antagonist Trichoderma spp. (Sharma et al., 2012; Contreras-Cornejo et al., 2013; Hermosa et 
al.,2013; Samolski et al., 2013; Qi and Zhao, 2013; Stewart and Hill, 2014). In a study conducted by Zhang et al., (2014a) revealed that Trichoderma longibrachiatum was found fairly effective for promoting plant growth and nematode control in wheat. Increased shoot and roots length, weight, of pod weight and number of nodules per plant was reported in peanut with $T$. harzianum among the four Trichoderma as compare to control treatment (Kamaruzzaman et al., 2016). The significant increase in yield (29\% and 36\%) of wheat (variety Raj 3765) was achieved by Sharma et al., (2012) with the application of Trichoderma harzianum (Th3) in Jaipur and Kota respectively in the field demonstrations at farmer's field conducted during 2008-2011 Martínez-Medina et al., (2014) reported that auxin production was induced and a decrease in cytokinins and abscisic acid content by Trichoderma isolates that promoted the plant growth. The biological activities of Trichoderma spp. in soil help in bioavailability of various nutrients and minerals either through chelation or solubilization, and thus make them available at the root surface of the plants (MenezesBlackburn et al., 2014) which results in increased plant growth.

\section{Tolerance to abiotic stress}

Abiotic stress (salt, drought etc.) play crucial role for crop cultivation as they limit in plant growth and subsequent yield in many areas. Some rhizospheric strains of Trichoderma are found fairly effective to induce plant growth under abiotic stresses (Bae et al., 2009; Mastouri et al., 2010; Shukla et al., 2012). Due to higher production and activity of ROS-scavenging enzymes (superoxide dismutase, catalase and ascorbate peroxidase) induced in tomato plants colonized with $T$. harzianum T22 under water-deficit stress condition results in enhanced plant growth (Mastouri et al., 2012). Under drought conditions, the cacao plants colonized with endophytic fungus Trichoderma hamatum isolate DIS 219b exhibited delayed droughtinduced changes in stomatal conductance and net photosynthesis (Bae et al., 2009). In a glass house study where mustard plants were raised with $T$. virens (Isolate PB23) treated seeds and subjected to water stress. The plants were able to thrive well and showed delayed response under water-deficit stress (Sharma and Singh, 2014). Trichoderma asperelloides - T203 was found to ameliorate seed germination under saline stress conditions due to its acquired tolerance to salt stress which is supposed to link with ACCD activity (Brotman et al., 2013). Inoculation of $A$. thaliana plants with Trichoderma resulted in significantly higher tolerance to salinity stress as compare to untreated plants which occur probably due to accumulation of antioxidant and stress hormone (Contreras-Cornejo et al., 2014b).

\section{Siderophores}

Siderophores (Gr. "iron-bearers") are low molecular weight, ferric specific legends which is to supply iron to the cell (Neilands, 1981) and iron is an essential element for various enzymatic reactions occur in living organisms although; naturally abundant ferric ion is almost insoluble in oxygenated environments and thus unavailable for microbial growth. Siderophores mediate the limited amount of iron in the rhizosphere, deprive pathogens of iron which produce less siderophores or different siderophores with lower binding coefficients and finally suppress their growth. Many reports have been published showing siderophore involvement in the suppression of plant pathogenic fungi (Vinale et al., 2013). T. virens produces three types of hydroxamate siderophores: a monohydroxamate (cis- and trans-fusarinines), a dipeptide of transfusarinine (dimerum acid), and a trimer disdepsipeptide (Lorito et al., 1993). 


\section{Metabolism of germination stimulants}

Propagules (sclerotia) of soil borne phytopathogens may germinate only in response to root exudates (germination stimulants) of host plants (Metcalf et al., 2004) however, some of the non-pathogenic organisms may also prefer to utilize these compounds. Thus, a relatively new concept 'inhibition of germination stimulants' is supposed to be a indirect mechanism of biocontrol and correlated with those nonpathogenic organisms where mycoparasitism / antibiosis is not established. Howell (2002) reported that control of pre-emergence damping off of cotton seedlings incited by $P$. ultimum and/or Rhizopus oryzae by T. virens (Strain G6, G6-5) or protoplast fusants of T.virens / $T$. longibrachiatum was due to metabolism of germination stimulants released by the cotton seed.

\section{Application methods and factors affecting efficacy}

The main problem in developing Trichoderma based bio-pesticides is that it represents a living system which should remain sufficiently viable for a period until it reaches to farmers (Vidhyasekaran and Muthamilan, 1995). Here, formulation helps to retain viability of bio-agent during preparation, storage and favours survival in the environment after application. Furthermore, it is quite essential to have an efficient, economic and ecologically viable delivery system or mode of application of bio-control agents in soil ecosystem and fairly good work has been done on this aspect under different conditions. Inoculation of seeds, corms, bulbs, tuber, etc. with antagonists prevents seed/corm decay and seedling blight. $T$. harzianum, $T$. virens and $T$. viride are effective seed protectants against Pythium spp. and Rhizoctonia solani (Jayaraj and Radhakrishana, 2003). According to Dutta and Das, (2002), soil application of Trichoderma spp. at the time of seedling planting reduced the collar rot in tomato as compare to seed treatment. Several reports depict the effectiveness of bio-control as foliar spray against different plant pathogens however, success of these antagonists depends largely on their ability to colonize on leaf/sheath surface (Lo et al., 1997).

For successful colonization of Trichoderma in rhizhosphere / phyllosphere, the minimum inoculum is crucial and subsequent action to initiate the various mechanisms through which bio-agents inhibit, restrict even kill the pathogen directly or indirectly. Adequate amount of soil moisture, temperature near ambient and definite rage of $\mathrm{P}^{\mathrm{H}}(5.5-7.5)$ is needed for growth and multiplication of Trichoderma species to perform their biocontrol activity in soil. Against Rhizoctonia solani in pea and rajma Trichoderma harzianum is more effective in acidic $\mathrm{P}^{\mathrm{H}}>\mathrm{pH}$ 6.5 (Singh et al., 2006). Changes of $4^{\circ} \mathrm{C}$ or 5 per cent $\mathrm{RH}$ are associated with variability in disease suppression by Trichoderma that may range from 25-100 per cent (Hannusch and Boland, 1996).

\section{Global and Indian scenerio of bio- pesticides}

Present share of bio-pesticides is only $5 \%$ of the total crop protection market globally which was valued about $\$ 3$ billion worldwide (Olson, 2015). Majority of Trichoderma based bio-pesticides globally are dominated by $T$. harzianum and $T$. viride (Gardener and Fravel, 2002; Koul, 2011 and Table 1). In India, only 15 types of bio-pesticides with more than 970 product are registered and more than 63 Indian private companies including Pest Control (Pvt) Ltd; Multiplex Biotech Ltd., International Panacea, Biotech International Ltd; T. Stanes; etc. have their registered products as bio-pesticide. 
Table.1 List of microbial pesticides developed from Trichoderma sp.

\begin{tabular}{|c|c|c|c|c|}
\hline Bio-agent & Target pest & Action & Brand name & Producer \\
\hline \multirow[t]{8}{*}{$\begin{array}{l}\text { Trichoderma } \\
\text { harzianum }\end{array}$} & \multirow{8}{*}{$\begin{array}{l}\text { Effective against } \\
\text { variety of soil borne } \\
\text { pathogens and } \\
\text { wound pathogens }\end{array}$} & \multirow{8}{*}{$\begin{array}{l}\text { Mycoparasitic, } \\
\text { Cell wall } \\
\text { degrading } \\
\text { enzymes } \\
\text { (CWDE), ISR }\end{array}$} & Root Shield & $\begin{array}{l}\text { BioWorks Inc, } \\
\text { NewYork }\end{array}$ \\
\hline & & & BioTrek 22g & $\begin{array}{l}\text { Wilbur-Ellis Co., } \\
\text { Fresno CA }\end{array}$ \\
\hline & & & Supresivit & $\begin{array}{l}\text { Borregaard, } \\
\text { Denmark }\end{array}$ \\
\hline & & & $\mathrm{T}-22 \mathrm{G}$ & Bioworks Inc, EU \\
\hline & & & $\mathrm{T}-22 \mathrm{HB}$ & \\
\hline & & & Trianum $\mathrm{P}$ & $\begin{array}{l}\text { Koppert Biological } \\
\text { Systems }\end{array}$ \\
\hline & & & Binab & $\begin{array}{l}\text { BINAB Bio } \\
\text { Innovation } \mathrm{AB}, \\
\text { Sweden }\end{array}$ \\
\hline & & & Trichodex & $\begin{array}{l}\text { Makhteshim } \\
\text { Chemical Works } \\
\text { LTD, Israel }\end{array}$ \\
\hline \multirow{6}{*}{$\begin{array}{l}\text { Trichoderma } \\
\text { viride }\end{array}$} & \multirow{6}{*}{$\begin{array}{l}\text { Effective against soil } \\
\text { borne pathogens } \\
\text { causing root rot } \\
\text { diseases }\end{array}$} & \multirow{6}{*}{$\begin{array}{l}\text { Mycoparasitic, } \\
\text { Anibiosis, PGP }\end{array}$} & Ecosom TV & AgriLife, India \\
\hline & & & Tricon & Green Max, India \\
\hline & & & & AgroTech, India \\
\hline & & & Trieco & $\begin{array}{l}\text { Ecosense labs, } \\
\text { India }\end{array}$ \\
\hline & & & $\begin{array}{l}\text { Bioderma/ } \\
\text { Protector }\end{array}$ & $\begin{array}{l}\text { Biotech } \\
\text { International Ltd., } \\
\text { New Delhi }\end{array}$ \\
\hline & & & Ecofit & $\begin{array}{l}\text { Eastman Kodak } \\
\text { Company, } \\
\text { New York }\end{array}$ \\
\hline \multirow{5}{*}{$\begin{array}{l}\text { Trichoderma } \\
\text { Sp. OR } \\
\text { T. harzianum } \\
+ \text { T. viride }\end{array}$} & \multirow{5}{*}{$\begin{array}{l}\text { Effective against } \\
\text { Armillaria and, } \\
\text { Botryoshaeria and } \\
\text { other root pathogens }\end{array}$} & \multirow{5}{*}{$\begin{array}{l}\text { Mycoparasitic, } \\
\text { Competition }\end{array}$} & Trichodry & \multirow{5}{*}{$\begin{array}{l}\text { Agrimm } \\
\text { Technologies Ltd., } \\
\text { New Zealand }\end{array}$} \\
\hline & & & Vinevax & \\
\hline & & & Trichopel & \\
\hline & & & Trichoject & \\
\hline & & & Trichoseal & \\
\hline $\begin{array}{l}\text { Trichoderma } \\
\text { polysporum + } \\
\text { T. harzianum }\end{array}$ & $\begin{array}{l}\text { Against wood decay } \\
\text { and wounds of } \\
\text { ornamental, shade, } \\
\text { and forest trees }\end{array}$ & & Binab T & $\begin{array}{l}\text { Binab Bio- } \\
\text { Inovation, EFTR } \\
\text { AB, Sweden }\end{array}$ \\
\hline $\begin{array}{l}\text { Gliocladium } \\
\text { virens } \\
\text { GL-21 }\end{array}$ & $\begin{array}{l}\text { Damping off and } \\
\text { root rot pathogens of } \\
\text { nursery ornamental }\end{array}$ & $\begin{array}{l}\text { Mycoparasitic, } \\
\text { Antbiosis, } \\
\text { Competition, } \\
\text { CWDE }\end{array}$ & SoilGard & Certis USA \\
\hline
\end{tabular}

(Gardener and Fravel, 2002; Koul, 2011) 
Microbial pesticides market in India dominated by sale of Trichoderma viride, Pseudomonas fluorescens and Bacillus thuringensis and Trichoderma alone shared $52.5 \%$ in the Indian bio-fungicides market in 2015 (Ken research Report, 2015). Funding for the research and production of bio pesticides and their promotion also is being led by the Department of Biotechnology (DBT) and Indian Council for Agricultural Research (ICAR) who support 22 and 31 biocontrol production facilities respectively in India. For reducing complications in registration, some amendments are made in Insecticide Act of 1968 for speedy development of bio-pesticides. In India, the bio-control products are promoted by the Governments through subsidies, demonstration, training etc. and strict quality control protocols are followed to maintain its quality and efficacy. However, the major constraints for popularizing and marketing of bio-control agents (BCAs)/bio-pesticides In India can be directly correlated with factors such as lack of awareness about the use of bio-pesticides and related products, high cost and time consuming registration procedures, unreliable quality standards and product availability. Moreover, pesticide market is leaded by unorganized stakeholders and synthetic pesticides are easily availability than bio-pesticides.

\section{Future prospects}

Research findings with the use of molecular, biochemical, physiological and genetical study tools have explored a wide area of research on various mechanisms employed by Trichoderma in its biocontrol activities. Future research should be carried out efficiently on participatory mode with publicprivate sector approach for encouraging investment in bio-pesticide and bio-fertilizer enterprises. Additional funding for innovative
R\&D for improvement of a particular microbial bio-pesticide by using unique sources (nanosilica, chitosan) will be needed. Development of consortium of two or more species or strains of Trichoderma in addition to liquid formulations is another area for increasing self-life and efficient delivery system at farmer's field.

\section{References}

Abdullah, M.T., Ali, N.Y. and Suleman P. (2008). Biological control of Sclerotinia sclerotiorum (Lib.) de Bary with Trichoderma harzianum and Bacillus amyloliquefaciens. Crop Prot., 27: 1354-1359.

Atanasova, L., Le-Crom, S., Gruber, S. Coulpier, F., SeidlSeiboth, V., Kubicek, C.P. and Druzhinina, I. (2013). Comparative transcriptomics reveals different strategies of Trichoderma mycoparasitism. BMC Genomics, 14: 121.

Bae, H., Roberts, D.P., Lim, H.S., Strem, M.D., Park, S.C., Ryu, C.M., Melnick, R.L., Bailey, B. (2011). Endophytic Trichoderma isolates from tropical environments delay disease onset and induce resistance against Phytophthora capsici in hot pepper using multiple mechanisms. Mol. Plant Microbe Interact., 24(3): 36-51.

Bae, H., Sicher, R.C., Kim, M.S., Kim, S.H., Strem, M.D., MeInice, R.L. and Bailey, B.A. (2009). The beneficial endophyte Trichoderma hamatum isolate DIS 219b promotes growth and delays the onset of the drought response in Theobroma cacao. J. Exp. Bot., 60(32): 3279-3295.

Bae, S.J., Mohanta, T.K., Chung, J.Y., Ryua, M., Park, G., Shim, S., Hong, S.B., Seo, H., Bae, D.W., Bae, I., Kima, J.J. and Bae, H. (2016). Trichoderma 
metabolites as biological control agents against Phytophthora pathogens. Biol Control, 92: 128-138.

Balakrishnan Sowmya, Gomathi, D., Kalaiselvi, M., Ravikumar, G., Arulraj, C. and Uma, C. (2012). Production and purification of chitinase by Streptomyces sp. from soil. J. Advanced Scientific Research., 3(3): 2-29.

Barakat, F. M., Abada, K. A., Abou-Zeid, N. M. and El-Gammal, Y. H. E. (2013). Effect of volatile and non-volatile compounds of Trichoderma spp. on Botrytis fabae the causative agent of faba bean chocolate spot. J. Agric. Res., 1(3): 42-50.

Contreras-Cornejo, H. A., Macias-Rodriguez, L., del-Val, E., and Larsen, J. (2016). Ecological functions of Trichoderma spp. and their secondary metabolites in the rhizosphere: interactions with plants. FEMS Microbiol. Ecol. 92(4): fiw036.

Contreras-Cornejo, H. A., Macías-Rodríguez, L. I., Alfaro-Cuevas, R., and LópezBucio, J. (2014a). Trichoderma spp. improve growth of Arabidopsis seedlings under salt stress through enhanced root development, osmolite production, and $\mathrm{Na}+$ elimination through root exudates. Mol. PlantMicrobe Interact., 27: 503-514.

Contreras-Cornejo, H. A., Macías-Rodríguez, L. I., Herrera-Estrella, A., and LópezBucio, J. (2014b). The 4phosphopantetheinyl transferase of Trichoderma virens plays a role in plant protection against Botrytis cinerea through volatile organic compound emission. Plant Soil., 379: 261-274.

Contreras-Cornejo, H. A., Ortiz-Castro, R., and López-Bucio, J. (2013). "Promotion of plant growth and the induction of systemic defence by
Trichoderma: physiology, genetics and gene expression," In Trichoderma: Biology and Applications, eds P. K. Mukherjee, B. A. Horwitz, U. S. Singh, M. Mukherjee, and M. Schmoll (Walingford: CABI), 173-194.

Contreras-Cornejo HA, Macías-Rodríguez L, Beltrán-Peña E, Alfredo HerreraEstrella A, López-Bucio J (2011). Trichoderma-induced plant immunity likely involves both hormonal- and camalexin-dependent mechanisms in Arabidopsis thaliana and confers resistance against necrotrophic fungus Botrytis cinerea. Plant Signal Behav., 6(10): 1554-1563.

Crutcher, F.K., Parich, A., Schuhmacher, R., Mukherjee, P.K., Zeilinger, S. and Kenerley, C.M. (2013). A putative terpene cyclase, vir4, is responsible for the biosynthesis of volatile terpene compounds in the biocontrol fungus Trichoderma virens. Fungal Genet. Biol., 56: 67-77.

Druzhinina IS, Seidl-Seiboth V, HerreraEstrella A, Horwitz BA, Kenerley CM, Monte E, Mukherjee PK, Zeilinger S, Grigoriev IV, Kubicek CP (2011). Trichoderma: the genomics of opportunistic success. Nat Rev Microbiol. 9(10): 749-59.

Dutta, P. and Das, B.C. (2002). Management of collar rot of tomato by Trichoderma spp. and chemicals. Indian Phytopathol., 55 (2): 235-237.

Gardener, M.B.B., and Fravel, D.R. (2002). Biological control of plant pathogens: Research, commercialization, and application in the USA. Online. Plant Health Progress, doi: 10.1094/PHP2002-0510-01-RV.

Garnica-Vergara, A., Barrera-Ortiz, S., Muñoz-Parra, E., Raya-González, J., Méndez-Bravo, A., MacíasRodríguez, L., Francisco Ruiz-Herrera 
L. and López-Bucio, J. (2016). The volatile 6-pentyl-2H-pyran-2-one from Trichoderma atroviride regulates Arabidopsis thaliana root morphogenesis via auxin signaling and Ethylene Insensitive 2 functioning. New Phytol., 209: 14961512.

Hannusch, D.J. and Boland, G.J. (1996). Influence of air temperature and relative humidity on biological control of white mold of bean (Sclerotinia sclerotiorum). Phytopathology, 86 (2): 156-162.

Harman, G.E., Howell, C.R., Viterbo, A., Chet, I. and Lorito, M. (2004). Trichoderma species-Opportunistic, avirulent plant symbionts. Nature Rev., 2: 43-56.

Hermosa, R., Rubio, M.B., Cardoza, R.E., Nicolás, C., Monte, E., and Gutiérrez, S. (2013). The contribution of Trichoderma to balancing the costs of plant growth and defense. International Microbiology, 16: 6980.

Howell C.R., (2002). Cotton seedling preemergence damping off incited by Rhizopus oryzae and Pythium spp. and its biological control with Trichoderma spp. Phytopathology. 92: 177-180

Jayaraj, J. and Radhakrishnan, N.V. (2003). Development of UV-induced carbendazim-resistant mutants of Trichoderma harzianum for integrated control of damping-off disease of cotton caused by Rhizoctonia solani. Zeitschrift fur Pflanzenkrankheiten und Pflanzenschutz, 110 (5): 449-460.

Kamaruzzaman, M., Rahman,M.M. and Ahmad, M.U. (2016). Efficacy of four selective Trichoderma isolates as plant growth promoters in two peanut varieties. International Journal of Biological Research, 4(2): 152-156.

Ken research Report (2015). Courtesy: India Biopesticide Market Outlook: Growth, trends and Market forecast to 2020.

Koul A. (2011). Microbial biopesticides: opportunities and challenges. $\mathrm{CAB}$ Reviews: Perspectives in Agriculture, Veterinary Science, Nutrition and Natural Resources, 2011, 6(56): 1-26.

Lo, C.T., Nelson, E.B. and Harman, G.E. (1997). Improved biocontrol efficacy of Trichoderma harzianum 1295-22 for foliar phases of turf diseases by use of spray applications. Plant Dis., 81 (10): 1132-1138.

Martínez-Medina, A, Maria Del Mar Alguacil, Jose A. Pascual, Saskia, C.M. and Van Wees (2014). Phytohormone profiles induced by Trichoderma isolates correspond with their biocontrol and plant growthpromoting activity on melon plants. $J$ Chem Ecol, 40:804-815.

Mastouri, F., Bjorkman, T., and Harman, G. E. (2012). Trichoderma harzianum enhances antioxidant defense of tomato seedlings and resistance to water deficit. Mol. Plant Microbe Interact., 25, 1264-1271.

Mastouri, F., Bjorkman, T., and Harman, G. E. (2010). Seed treatment with Trichoderma harzianum alleviates biotic, abiotic, and physiological stresses in germinating seeds and seedlings. Phytopathology, 100: 12131221.

Menezes-Blackburn, D., Jorquera, M.A., Gianfreda, L., Greiner, R., de la Luz Mora, M. (2014). A novel phosphorus biofertilization strategy using cattle manure treated with phytase-nanoclay complexes. Biol Fertil Soils, 50: 583592.

Metcalf, D.A., Dennis, J.J.C. and Wilson, C.R. (2004). Effect of inoculum 
density of Sclerotium cepivorum on the ability of Trichoderma koningii to suppress white rot of onion. Plant Disease, 88:287-291.

Mukherjee, P.K., Horwitz, B.A. and Kenerley, C.M. (2012a). Secondary metabolism in Trichoderma - a genomic perspective. Microbiology, 158: $35-45$.

Mukherjee PK, Buensanteai, N., Moran-Diez, ME. (2012a). Functional analysis of nonribosomal peptide synthetases (NRPSs) in Trichoderma virens reveals a polyketide synthase (PKS)/NRPS hybrid enzyme involved in the induced systemic resistance response in maize. Microbiology, 158: 155-165.

Neilands, J. B. (1981). Microbial iron compounds. Annu. Rev. Biochem., 50: $715-731$.

Olson, S. (2015). An analysis of the biopesticide market now and where is going. Outlooks Pest Manag., 26: 203 206.

Pal, K.K. and Gardener M.B. (2006). Biological Control of Plant Pathogens The Plant Health Instructor. DOI: 10.1094/PHI-A-2006-1117-02.

Qi W. Z., Zhao L. (2013). Study of the siderophore-producing Trichoderma asperellum Q1 on cucumber growth promotion under salt stress. J. Basic Microbiol. 53 355-364.

Rawat, R. and Tewari, L. (2010). Transmission electron microscopic study of the cytological changes in Sclerotium rolfsii parasitized by a biocontrol fungus Trichoderma species. Mycology: An International J. Fungal Biology., 1(4): 237-241.

Reino, J.L., Guerrero, R.F., Hernández-Galán, R. and Collado, I.G. (2008). Secondary metabolites from species of the biocontrol agent Trichoderma. Phytochem. Rev., 7: 89-123.
Sahebani, N. and Hadavi, N. (2008). Biological control of the root-knot nematode Meloidogyne javanica by Trichoderma harzianum. Soil Biology and Biochemistry, 40, 2016-2020.

Saksirirat, W., Chareerak, P. and Bunyatrachata, W. (2009). Induced systemic resistance of biocontrol fungus, Trichoderma spp. against bacterial and gray leaf spot in tomatoes. Asian J. Food AgroIndustry, 2: S99-S104.

Samolski, I., Rincón, A., Pinzón, L.M. et al., (2012). The qid74 gene from Trichoderma harzianum has a role in root architecture and plant biofertilization. Microbiology, 158(1): 29-38.

Sharma, K.K. (2017). Induction of systemic resistance (ISR) against sheath blight of rice caused by Rhizoctonia solani Kuhn using biological seed treatment with Trichoderma. Journal of Applied and Natural Science, 9(3): 1861-1865.

Sharma, K.K. (2017). Qualitative enzyme essay and sclerotia parasitization by fungal antagonist Trichoderma. The Bioscan (Supplement on Plant Pathology), 11(4): 2867-2872.

Sharma, K.K. and Singh U.S. (2014). Induction of water stress tolerance of mustard plants using Trichoderma as seed treatment. Journal of Applied and Natural Science, 6(2): 436-441.

Sharma, P., Patel, A.N, Saini, M.K. and Swati Deep (2012). Field Demonstration of Trichoderma harzianum as a Plant Growth Promoter in Wheat (Triticum aestivum L). Journal of Agricultural Science, 4(8): 65-73.

Sharon, E., Bar-Eyal, M., Chet, I., HerreraEstrella, A., Kleifeld, O. and Spiegel, Y. (2001). Biological control of the root knot nematode Meloidogyne javanica by Trichoderma harzianum. Phytopathology, 91: 687-693. 
Shentu, X.P., Liu, W.P., Zhan, X.H., Yu, X.P. and Zhang, C.X. (2013). The elicitation effect of pathogenic fungi on trichodermin production by Trichoderma brevicompactum. Sci. World J., DOI: 10.1155/2013/607102

Shoresh, M., Harman, G. E. and Mastouri, F. (2010). Induced systemic resistance and plant responses to fungal biocontrol agents. Annu Rev Phytopathol., 48: 21-43.

Shoresh, M., Yedidia, I. and Chet, I. (2005). Involvement of jasmonic acid/ethylene signaling pathway in the systemic resistance induced in cucumber by Trichoderma asperellum T203. Phytopathology 95: 76-84.

Shukla, N., Awasthi, R.P. and Rawat, L. (2012). Biochemical and physiological responses of rice (Oryza sativa L.) as influenced by Trichoderma harzianum under drought stress. Plant Physiol. Biochem., 54: 78-88.

Singh, U.S., Mishra, D.S., Rohilla, R., Singh, A. and Vishwanath. (2001b). Induced resistance: present status and future prospects as disease management strategy. In: Biopesticides and Pest Management (Opender Kaul, G.S. Dhaliwal, S.S. Marwaha, and J. Arora, eds.), Campus Book International, New Delhi. Degradation of fungal cell walls by lytic enzymes of Trichoderma harzianum.

Singh, U.S., Zaidi, N.W., Joshi, D., Varshney, S. and Khan, T. (2006). Current status of Trichoderma as a biocontrol agent. In: Ramanujam B, Rabindra RJ (eds) Current status of biological control of plant diseases using antagonistic organisms in India, Project Directorate of Biological Control, Bangalore.

Stewart, A. and Hill, R. (2014). Applications of Trichoderma in Plant Growth Promotion. In: Biotechnology and
Biology of Trichoderma, Publisher(s): Elsevier BV; Elsevier, Pp: 415-428.

Tijerino, A., Cardoza, R.E., Moraga, J., Malmierca, M.G. and Vicente, F. et al., (2011). Overexpression of the trichodiene synthase gene tri5 increases trichodermin production and antimicrobial activity in Trichoderma brevicompactum. Fungal Genet. Biol., 48: 285-296.

Tsahouridou, P.C. and Thanassoulopoulos, C.C. (2002). Proliferation of Trichoderma koningii in the tomato rhizosphere and the suppression of damping-off by Sclerotium rolfsii. Soil Biol Biochem., 34(6): 767-776.

Vidhyasekaran, P. and Muthamilan, M. (1995). Development of formulations of Pseudomonas fluorescens for the control of chickpea wilt. Plant Dis., 79: 782-786.

Vinale, F., Nigro, M., Sivasithamparam, K., Flematti, G., Ghisalberti, E.L., Ruocco, M., Varlese, R., Marra, R., Lanzuise, S., Eid, A., Woo, S.L. and Lorito, M. (2013). Harzianic acid: a novel siderophore from Trichoderma harzianum. FEMS Microbiol. Lett., 347(2): 123-129.

Vinale, F., Sivasithamparam, K., Ghisalberti, E.L., Woo, S.L., Nigro, M., Marra, R., Lombardi, N., Pascale, A., Ruocco, M., Lanzuise, S., Manganiello, G. and Lorito, M. (2014). Trichoderma secondary metabolites active on plants and fungal pathogens. Mycol. J., 8: 127-139.

Viterbo. A., Montero, M., Ramot, O., Friesem, D., Monte, E., Liobell, A. and Chet, I. (2002). Experssion regulation of the endochitinase chit 39 from Trichoderma asperellum ( $T$. harzianum T-203). Curr. Genet., 42: 114-122.

Wilhite SE, Lumsden RD and Straney DC. (2001). Peptide synthetase gene in 
Trichoderma virens. Applied and Environmental Microbiology, 67: 5055-5062.

Yedidia, I., Shoresh, M., Kerem, Z., Benhamou, N., Kapulnik, Y. and Chet, I. (2003). Concomitant induction of systemic resistance to Pseudomonas syringae pv. Lachrymans in cucumber by Trichoderma asperellum (T-203) and accumulation of phytoalexins. Applied and Environmental Microbiology. 69(12): 7343-7353.

Zhang, S., Gan, Y. and Xu, B. (2016). Application of plant-growthpromoting fungi Trichoderma longibrachiatum T6 enhances tolerance of wheat to salt stress through improvement of antioxidative defense system and gene expression. Front Plant Sci., 2016(7): 1-11.

Zhang S. W., Gan Y. T., Xu B. L. (2014a). Efficacy of Trichoderma longibrachiatum in the control of Heterodera avenae. BioControl 59 319-331.

Zhang S. W., Gan Y. T., Xu B. L. (2015). Biocontrol potential of a native species of Trichoderma longibrachiatum against Meloidogyne incognita. Appl. Soil Ecol. 94 21-29.

\section{How to cite this article:}

Sharma, K.K. 2018. Trichoderma in Agriculture: An Overview of Global Scenario on Research and its Application. Int.J.Curr.Microbiol.App.Sci. 7(08): 1922-1933.

doi: https://doi.org/10.20546/ijcmas.2018.708.221 